Doi: $10.4274 /$ vhd.29491

Viral Hepatitis Journal 2016; 22(1):1-5

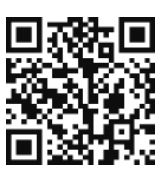

\title{
Antiviral Treatment During Breastfeeding in Hepatitis B
}

\author{
Hepatit B'de Emzirme Döneminde Antiviral Tedavi
}

\author{
Imran HASANOĞLU1, Rahmet GÜNER² \\ ${ }^{1}$ Atatürk Education and Research Hospital, Clinic of Infectious Diseases and Clinical Microbiology, Ankara, Turkey \\ ${ }^{2}$ YIIdırım Beyazıt University Faculty of Medicine, Department of Infectious Diseases and Clinical Microbiology, Ankara, Turkey
}

\begin{abstract}
From 1982, with the availability of hepatitis B vaccine, chronic hepatitis $B$ infection rate and its complications have decreased dramatically. Today, transmission from an infected woman to her newborn still remains as one of the major problems about hepatitis B. Guidelines recommend quantification of hepatitis B virus (HBV) DNA in all infected pregnant women at the end of the second trimester. Mothers with high concentrations of HBV DNA (>1.000.000 copies/ml) should be considered for antiviral therapy. Since the immune system is activated after delivery, continuing this therapy during the postpartum period remains critical in highly viremic mothers.

Some antiviral drugs are recommended during pregnancy. However, safety of these drugs during breastfeeding interestingly remains unclear. There are several studies regarding the use of lamivudine (LAM) and tenofovir disoproxil (TdF) while breastfeeding in human immunodeficiency virus (HIV)-infected mothers. The World Health Organization guidelines on HIV recommend HIV-infected mothers to continue antiretroviral treatment while breastfeeding. Applicability of this recommendation for HBV-infected mothers must be clarified.

Both clinicians and patients face therapeutic decisions regarding breastfeeding in hepatitis $\mathrm{B}$, which are not based on randomized controlled trials. They have to make a hard decision to choose the best option considering both the benefits of breastfeeding and the need for antiviral treatment, where indicated, to have a healthy mother, which seem to contradict to some extent. In the light of up-to-date literature, if a mother needs antiviral treatment for HBV, LAM and TdF raise as options with advantages of enabling breastfeeding. However, further studies are urgently needed in this issue to make a recommendation supported by evidence-based medicine.
\end{abstract}

Keywords: Hepatitis B, breastfeeding, antiviral treatment

\section{ÖZ}

1982 yılında hepatit B aşısının kullanıımaya başlanması ile kronik hepatit B enfeksiyonu ve komplikasyonlarında dramatik bir düşüş gözlenmiştir. Günümüzde hala enfekte anneden bebeğe bulaş, hepatit B ile ilgili en büyük problemlerden birini oluşturmaktadır. Hepatit B virüsü (HBV) ile enfekte gebelerde ikinci trimestırda HBV DNA kantitasyonu yapılması önerilmektedir. HBV DNA düzeyi $1,000,000$ kopya/ml üzerinde olan gebelerin antiviral tedavi açısından değerlendirilmesi gerekmektedir. Postpartum dönemde gelişen immün sistem reaktivasyonu nedeniyle, antiviral tedavinin doğum sonrası dönemde de devam etmesi virüs titresi yüksek annelerde kritik öneme sahiptir. Bazı antiviral ilaçlar gebelik döneminde önerilseler de emzirme döneminde kullanımlarının güvenilirliği ile ilgili net bir veri bulunmamaktadır. Lamivudin (LAM) ve tenofovirin (TdF), insan bağışıklık yetmezlik virüsü (HIV) ile enfekte annelerde emzirme döneminde kullanımları ile ilgili çalışmaları vardır. Dünya Sağlık Örgütü HIV rehberinde HIV ile enfekte annelerin antiretroviral tedavi alırken emzirmeye devam edebilecekleri önerilmektedir. Bu önerinin HBV ile enfekte anneler için de net ortaya konması gerekmektedir.

Gerek klinisyenler gerekse hastalar günlük pratikte hepatit B ile enfekte annenin emzirme kararını, randomize kontrollü çalışmalara dayanmayan verilerle almak durumuyla karşı karşıya kalmaktadır. Hem emzirmenin faydalarını hem de hastaların antiviral tedavi gereksinimini göz önünde bulundururarak zor bir karar vermeleri gerekmektedir. Güncel bilgiler ışığında, bir annenin antiviral tedavi intiyacı varsa emzirmeye olanak sağlamaları nedeniyle LAM ve TdF iyi birer alternatif olarak karşımıza çıkmaktadır. Fakat yine de kanıta dayalı tıp ile desteklenmiş önerilerde bulunabilmek için daha fazla çalışmaya intiyaç vardır.

Anahtar Kelimeler: Hepatit B, emzirme, antiviral tedavi 


\section{Introduction}

Hepatitis B is a global health problem which affects approximately 400 million people worldwide. In spite of the global efforts to reduce hepatitis $B$ infection, it is estimated that 240 million people are chronically infected with hepatitis B and approximately 780.000 persons die each year from hepatitis B infection (1).

From 1982, with the availability of hepatitis B vaccine, chronic infection rate and its complications have decreased dramatically. Today, transmission from an infected woman to her newborn still remains as one of the major problems about hepatitis $B$. Close screening of both mother and child during pregnancy and the postpartum period is essential for the prevention of transmission and hepatic flares in the mother. Guidelines recommend quantification of hepatitis B virus (HBV) DNA in all infected pregnant women at the end of the second trimester. Mothers with high concentrations of HBV DNA (>1.000.000 copies/ml) should be considered for antiviral therapy $(2,3,4)$. After pregnancy, a significant increase in liver inflammation occurs. Since the immune system is activated after delivery, continuing this therapy during the postpartum period remains critical in highly viremic mothers (5). Some antiviral drugs are recommended during pregnancy, and there are several studies on this issue. However, safety of these drugs during breastfeeding interestingly remains unclear. Breast milk is a unique food for infants, and it is especially important in low-income countries. The advantages of breastfeeding for both mother and infant are unquestionable. Although the World Health Organization (WHO) recommends breastfeeding in chronic hepatitis B (CHB), unfortunately, 25-50\% medical professionals (most of whom are hepatologists) do not encourage these mothers to breastfeed their babies $(6,7)$. Even though HBV DNA is detected in breast milk (8), many studies suggest that breastfeeding is not a risk for mother-to-child transmission if the newborn is adequately managed for hepatitis B prevention at birth $(9,10)$. Moreover, the majority of the mother-to-child transmission happens before deciding on infants' feeding modes (11). Breastfeeding during antiviral treatment in hepatitis B is an unclear issue. All of these drugs' labels include a warning stating that breastfeeding is not recommended while taking these drugs. There are several studies on the use of lamivudine (LAM) and tenofovir disoproxil (TdF) while breastfeeding in human immunodeficiency virus (HIV)-infected mothers. The WHO guidelines on HIV recommend HIV-infected mothers to continue antiretroviral treatment while breastfeeding (12). Since LAM and TdF are parts of antiretroviral treatment recommended for HIV-infected mothers who breastfeed their babies, applicability of this recommendation for HBV-infected mothers must be clarified. The aim of this review is to summarize the data regarding antiviral treatment during breastfeeding in $\mathrm{CHB}$.

\section{Lamivudine}

LAM is a synthetic nucleoside analogue effective for both HBV and HIV-1. It is the first antiviral that was licensed for the treatment of HBV infection. Today, guidelines recommend using LAM in the treatment of $\mathrm{CHB}$ if more potent drugs are not available or appropriate (2). A randomized, placebo-controlled trial conducted on 150 hepatitis B surface antigen (HBsAg)-positive highly viremic pregnant women evaluated whether LAM prevented
HBV transmission to newborns who received standard prophylaxis with hepatitis B immunoglobulin ( $\mathrm{HBIG}$ ) and vaccination. After a 52-week follow-up, 18\% of babies from LAM-treated mothers were HBsAg-positive compared to $39 \%$ of those in placebo group $(p=0.014)$. No adverse events were noted in the LAM-treated mothers and their infants. This study supports that LAM reduces HBV transmission from highly viremic mothers to their infants who received passive/active immunization (13).

The US Food and Drug Administration (FDA) included LAM in the pregnancy category $C$ (Table 1,2) (14). Although it is classified as $\mathrm{C}$, LAM is the only antiviral against HBV and randomized controlled studies have proven the safety of LAM administration in pregnancy (13). Through 31 July 2015, the Antiretroviral Pregnancy Registry (APR) reported 4566 and 7263 women who have been exposed to LAM during the first and second/third trimesters, respectively. In these data, newborn defect rates were $3.1 \%$ for the first and $2.9 \%$ for the second/third trimesters, which are similar to the general population (15). In the Kisumu Breastfeeding Study, which evaluates antiretroviral concentrations at different time points in HIV-infected mothers, their breast milk, and infants, the median maternal plasma LAM concentration was $508 \mathrm{ng} / \mathrm{ml}$ and the breast milk concentration was $1214 \mathrm{ng} / \mathrm{ml}$. The concentration of LAM in the infant was highest on the day of birth compared to the other postpartum sampling times, even though infants were breastfeeding (16). Although LAM is concentrated in breast milk $(16,17,18)$, the amount that the infant has been exposed to is insignificant (which is approximately $2 \%$ of the recommended daily treatment dose of LAM) (16). Studies revealed that an infant is exposed to significantly higher LAM concentrations via umbilical cord than being exposed to via breast milk $(13,14)$.

\section{Tenofovir Disoproxil Fumarate}

Tenofovir disoproxil fumarate is a prodrug used because of its better bioavailability than $\mathrm{TdF}$ TdF is a nucleotide reverse transcriptase inhibitor. Since it has high barrier to resistance and potent inhibitory effect to HBV, it is one of the first-line therapies for CHB. TdF is labeled as pregnancy category B (Table 1) (19). Studies revealed that, like in LAM, infants are exposed to higher TdF concentrations via umbilical cord than that via breast milk (20). Benabound et al. (21) have reported in their study that among 5 women, the median maximal TdF concentration in breast milk was $14.1 \mathrm{ng} / \mathrm{ml}$ which is lower than the concentrations in both maternal serum and cord blood. Assuming that TdF in breast milk has low bioavailability because of not being a prodrug, the concentration of $\mathrm{TdF}$ in infants due to breast milk ingestion is probably insignificant. In an animal study among two lactating macaques, after the administration of a subcutaneous dose of $\mathrm{TdF}(30 \mathrm{mg} / \mathrm{kg}$ of body weight), it was observed that the TdF concentrations in breast milk of lactating macaques were unlikely to be toxic for the infant and that the small amounts of TdF in the milk were not likely to select for resistance in already infected infants (22). Similarly, Palombi et al. (23) reported in their long-term follow-up (12 months) study that passage of $\mathrm{TdF}$ into breast milk was negligible. It seems ironic that TdF has not been recommended while breastfeeding since its pregnancy risk is categorized as B. The APR reported 2608 and 1258 women who have been exposed to TdF during the first and second/third trimesters, respectively. In these data, newborn 
defect rates were $2.3 \%$ for the first and $2.1 \%$ for the second/third trimesters, which are similar to the general population (15). A study among 74 infants which evaluated fetal bone effects of maternal TdF use, reported that TdF-exposed infants had significantly lower body bone mineral density compared with unexposed infants (24). However, further studies are required to reveal the effect of TdF on infants' bone mineral density. With its increasing safety data in pregnant women, $\mathrm{TdF}$ can be considered as an option for antiviral treatment during breastfeeding in hepatitis B. However, further studies are required to evaluate the pharmacokinetics and pharmacodynamics of TdF in breastfeeding.

\section{Interferon- $\alpha$}

Interferon alpha (IFN- $\alpha$ ) is an immunomodulatory and antiviral agent which is licensed for the treatment of HBV infection since 1992. With the modification through the attachment of a polyethylene glycol molecule, pharmacokinetics and pharmacodynamics properties of IFN has improved and enabled its once weekly administration. IFN is labeled as pregnancy risk category $\mathrm{C}$ (Table 1). There are limited data on its usage during both pregnancy and breastfeeding. Data on this issue are based on case reports. Therefore, the safety of interferon during both pregnancy and breastfeeding is not clear enough.

In 1995, Pons et al. (25) reported two HIV-seropositive pregnant women given a single intramuscular dose of IFN-alpha, just before the abortion in the second trimester. They found undetectable IFN levels in the fetal blood and amniotic fluid in both cases. In another case report evaluating the transfer of IFN- $\alpha$ (2B) into breast milk of a patient, who was receiving high intravenous doses for the treatment of malignant melanoma, the authors have reported that after 30 million IU administration, the amount of interferon in the breast milk was only moderately elevated (1551 $\mathrm{IU} / \mathrm{mL})$ when compared to control milk (1249 IU/mL). This report suggests that even following very high doses, interferon is not excreted in breast milk, probably due to its large molecular size (26). Despite the limited clinical and laboratory studies, the US Drugs and Lactation Database (LactMed) reports that it is unlikely that IFN use by a nursing mother presents any serious risk to the breastfed infant because of the low levels in milk and poor oral absorption by the infant (27)

\section{Adefovir Dipivoxil}

Adefovir dipivoxil (ADV) is the prodrug of adefovir, an acyclic nucleotide phosphonate analogue of adenosine monophosphate, which is converted by host enzymes to adefovir diphosphate. ADV is assigned to FDA Pregnancy Category $C$ (Table 1) (28). There is no adequate data on the use of ADV during both pregnancy and breastfeeding. It is not known whether ADV is excreted in human milk. APR suggests that mothers should be instructed not to breastfeed if they are taking ADV (15).

\section{Entecavir}

Entecavir (ETV) is a guanosine nucleoside analogue which has activity against $\mathrm{HBV}$ reverse transcriptase. It is labeled as pregnancy risk category C (29). ETV has not been studied in both pregnancy and breastfeeding. Excretion of ETV to human breast milk is not known. Thus, its use in these situations cannot be recommended (26). Clinician together with the patient has to make a decision to discontinue breastfeeding or discontinue the drug.

\section{Telbivudine}

Telbivudine (LdT) is an HBV-specific synthetic thymidine nucleoside analogue. It is a potent inhibitor of HBV replication, but, due to a lower barrier to resistance, guidelines do not recommend LdT as the first-line monotherapy (2). A prospective study among 229 HBsAg-positive, HBeAg-positive pregnant women with high virus titers ( $>10^{7}$ copies $/ \mathrm{mL}$ ) evaluated the efficacy and safety of LdT vs untreated controls (30). All infants in both arms received $\mathrm{HBIG}$ within $12 \mathrm{~h}$ postpartum and HBV vaccine at 0,1 , and 6 months. The mothers received LdT $600 \mathrm{mg} /$ day from week 20 to 32 of gestation and continued for 4 weeks after delivery in the case of inactive disease and for 28 weeks in the case of active chronic hepatitis. The authors have reported that LdT treatment was associated with a noticeable decrease in serum HBV DNA and HBeAg levels and normalization of elevated alanine aminotransferase levels before delivery. Twenty-eight weeks after delivery, perinatal transmission was lower in the infants who born to the LdT-treated mothers than in controls. In this study, no serious adverse events were reported in the LdT-treated mothers or their infants. However, this study does not include any statement on

\begin{tabular}{|l|l|}
\hline \multicolumn{2}{|l|}{ Table 1. Food and drug administration pregnancy risk categories (34) } \\
\hline Risk category & Explanation \\
\hline A & $\begin{array}{l}\text { Adequate and well-controlled studies have failed to demonstrate a risk to the fetus in the first trimester of } \\
\text { pregnancy (and there is no evidence of risk in later trimesters) }\end{array}$ \\
\hline B & $\begin{array}{l}\text { Animal reproduction studies have failed to demonstrate a risk to the fetus and there are no adequate and well- } \\
\text { controlled studies in pregnant women }\end{array}$ \\
\hline C & $\begin{array}{l}\text { Animal reproduction studies have shown an adverse effect on the fetus and there are no adequate and well- } \\
\text { controlled studies in humans, but potential benefits may warrant use of the drug in pregnant women despite } \\
\text { potential risks }\end{array}$ \\
\hline D & $\begin{array}{l}\text { There is positive evidence of human fetal risk based on adverse reaction data from investigational or marketing } \\
\text { experience or studies in humans, but potential benefits may warrant use of the drug in pregnant women despite } \\
\text { potential risks }\end{array}$ \\
\hline X & $\begin{array}{l}\text { Studies in animals or humans have demonstrated fetal abnormalities and/or there is positive evidence of human } \\
\text { fetal risk based on adverse reaction data from investigational or marketing experience, and the risks involved in } \\
\text { use of the drug in pregnant women clearly outweigh potential benefits }\end{array}$ \\
\hline
\end{tabular}




\begin{tabular}{|l|l|l|}
\hline \multicolumn{3}{|l|}{$\begin{array}{l}\text { Table 2. Pregnancy risk categories and recommendations of antivirals } \\
\text { during breastfeeding }\end{array}$} \\
\hline Antiviral & $\begin{array}{l}\text { Pregnancy risk } \\
\text { category }\end{array}$ & During breastfeeding \\
\hline Lamivudine & C & $\begin{array}{l}\text { Can be used based on } \\
\text { clinical studies }\end{array}$ \\
\hline Tenofovir & B & $\begin{array}{l}\text { Can be used based on } \\
\text { clinical studies }\end{array}$ \\
\hline Interferon & C & Not recommended \\
\hline Adefovir & C & Not recommended \\
\hline Entecavir & C & Not recommended \\
\hline Telbivudine & B & Not recommended \\
\hline
\end{tabular}

breastfeeding while taking $L d T$. Despite $L d T$ is labeled as pregnancy risk category B (31), there are no adequate and well-controlled studies on the LdT usage in pregnant women. Moreover, excretion of LdT to human breast milk is not known. To recommend its use during breastfeeding, pharmacokinetics and pharmacodynamics of LdT have to be better known in the nursing mothers with HBV. All of these drugs mentioned above can be used in CHB. However, when the patient is a breastfeeding mother with hepatitis $B$, LAM and $\mathrm{TdF}$ remain as eligible treatment options. Although there are clinical studies on the use LAM both pregnancy and breastfeeding, due to high probability of resistance to LAM, TdF can be safer for a breastfeeding mother with $\mathrm{CHB}(32,33)$.

\section{Conclusion}

Since hepatitis B is a global health problem among women of reproductive age, both clinicians and patients face therapeutic decisions which are not based on randomized controlled trials. They have to make a hard decision to choose the best option considering both the benefits of breastfeeding and the need for antiviral treatment, where indicated, to have a healthy mother which seem to contradict to some extent. The benefits of breastfeeding for both mother and infant are unquestionable. On the other hand, antiviral treatment is crucial for the mother's health. In the light of up-to-date literature, if a mother needs antiviral treatment for HBV, LAM and $\mathrm{TdF}$ raise as options with advantages of enabling breastfeeding (34). Among these two antivirals, TdF seems to be more preferable due to its safer pregnancy risk category and high barrier to resistance. However, further studies are urgently needed in this issue to make a recommendation supported by evidence-based medicine.

\section{Ethics}

Peer-review: External and Internal peer-reviewed.

\section{Authorship Contributions}

Concept: Rahmet Güner, Design: Rahmet Güner Analysis or Interpretation: Imran Hasanoğlu, Literature Search: Imran Hasanoğlu, Writing: Imran Hasanoğlu, Rahmet Güner.

Conflict of Interest: No conflict of interest was declared by the authors.

Financial Disclosure: The authors declared that this study has received no financial support.

Hasanoğlu I, Güner R. Antiviral Treatment During Breastfeeding in Hepatitis B. Viral Hepatitis J 2016;22:1-5.

\section{References}

1. WHO I Hepatitis B [Internet]. WHO. [cited 2015 Nov 30]. Available from: http://www.who.int/mediacentre/factsheets/ fs204_Jul2014/en/

2. European Association For The Study Of The Liver. EASL clinical practice guidelines: Management of chronic hepatitis B virus infection. J Hepatol. 2012;57:167-185.

3. Celen MK, Mert D, Ay M, Dal T, Kaya S, Yildirim N, Gulsun S, Barcin T, Kalkanli S, Dal MS, Ayaz C. Efficacy and safety of tenofovir disoproxil fumarate in pregnancy for the prevention of vertical transmission of HBV infection. World J Gastroenterol. 2013;19:9377-9382.

4. Tekin Koruk S, Batirel A, Kose S, Cetin Akhan S, Aygen B, Tulek N, Hatipoglu C, Bulut C, Yıldız O, Sacligil C, Sirmatel F, Altunok E. Evaluation of hepatitis B virus transmission and antiviral therapy among hepatitis B surface antigen-positive pregnant women. J Obstet Gynaecol Res. 2015;41:1870-1876.

5. Ertürk A, Cüre E, Parlak E, Cüre MC, Çapur Çlçek A, Kır Şahin F. Evaluation of the Results of Antiviral Therapy in Pregnant Women with Chronic Hepatitis B. Viral Hepatits J. 2014;20:2327.

6. Ahn J, Salem SB, Cohen SM. Evaluation and management of hepatitis B in pregnancy: a survey of current practices. Gastroenterol Hepatol (N Y). 2010;6:570-578.

7. Giles ML, Garland SM, Grover SR, Lewin SM, Hellard ME. Impact of an education campaign on management in pregnancy of women infected with a blood-borne virus. Med J Aust. 2006;184:389-392

8. de Oliveira PR, Yamamoto AY, de Souza CB, de Araújo NM, de Andrade Gomes S, Heck AR, de Castro Figueiredo JF, Mussi-Pinhata MM. Hepatitis B viral markers in banked human milk before and after Holder pasteurization. J Clin Virol. 2009;45:281-284.

9. Chen $X$, Chen J, Wen J, Xu C, Zhang S, Zhou YH, Hu Y. Breastfeeding is not a risk factor for mother-to-child transmission of hepatitis B virus. PloS One. 2013;8:55303.

10. Shi $Z$, Yang $Y$, Wang $H$, Ma $L$, Schreiber $A$, Li $X$, Sun $W$, Zhao $X$, Yang $X$, Zhang L, Lu W, Teng J, An Y. Breastfeeding of newborns by mothers carrying hepatitis $B$ virus: a metaanalysis and systematic review. Arch Pediatr Adolesc Med. 2011;165:837-846

11. Zheng Y, Lu Y, Ye Q, Xia Y, Zhou Y, Yao Q, Wei S. Should chronic hepatitis $B$ mothers breastfeed? a meta analysis. BMC Public Health. 2011;11:502.

12. Hirnschall G, Harries AD, Easterbrook PJ, Doherty MC, Ball A. The next generation of the World Health Organization's global antiretroviral guidance. J Int AIDS Soc. 2013;16:18757.

13. Xu W-M, Cui Y-T, Wang L, Yang H, Liang Z-O, Li X-M, Zhang SL, QIAO FY, Campbell F, Chang CN, Gardner S, Atkins M. Lamivudine in late pregnancy to prevent perinatal transmission of hepatitis B virus infection: a multicentre, randomized, doubleblind, placebo-controlled study. Viral Hepatitis J. 2009;16:94-103.

14. Lamivudine Use During Pregnancy I Drugs.com [Internet]. [cited 2016 Mar 20]. Available from: http://www.drugs.com/ pregnancy/lamivudine.html

15. FDA Pregnancy Categories A, B, C, D, X, N Explained [Internet]. [cited 2016 Mar 20]. Available from: http://www.drugs.com/ pregnancy-categories.html

16. APR [Internet]. WHO. [cited 2015 Dec 17]. Available from: http://www.apregistry.com/InterimReport.aspx

17. Mirochnick M, Thomas T, Capparelli E, Zeh C, Holland $D$, Masaba R, Odhiambo P, Fowler MG, Weidle PJ, Thigpen MC. Antiretroviral concentrations in breast-feeding infants of 
mothers receiving highly active antiretroviral therapy. Antimicrob Agents Chemother. 2009;53:1170-1176.

18. Giuliano M, Guidotti G, Andreotti M, Pirillo MF, Villani P, Liotta G, Marazzi MC, Mancini MG, Cusato M, Germano P,Loureiro S, Ceffa S, Regazzi M, Vella S, Palombi L. Triple antiretroviral prophylaxis administered during pregnancy and after delivery significantly reduces breast milk viral load: a study within the Drug Resource Enhancement Against AIDS and Malnutrition Program. J Acquir Immune Defic Syndr. 2007;44:286-291.

19. Shapiro RL, Holland DT, Capparelli E, Lockman S, Thior I, Wester C, Stevens L, Peter T, Essex M, Connor JD,Mirochnick M. Antiretroviral concentrations in breast-feeding infants of women in Botswana receiving antiretroviral treatment. J Infect Dis. 2005;192:720-727.

20. Tenofovir (Viread) Use During Pregnancy [Internet]. [cited 2016 Mar 20]. Available from: http://www.drugs.com/pregnancy/ tenofovir.html

21. Benaboud $S$, Pruvost A, Coffie PA, Ekouévi DK, Urien S, Arrivé E, Blanche S, Théodoro F, Avit D, Dabis F, Tréluyer JM, Hirt D. Concentrations of tenofovir and emtricitabine in breast milk of HIV-1-infected women in Abidjan, Cote d'Ivoire, in the ANRS 12109 TEmAA Study, Step 2. Antimicrob Agents Chemother. 2011;55:1315-1317.

22. Van Rompay KK, Hamilton M, Kearney B, Bischofberger $N$. Pharmacokinetics of tenofovir in breast milk of lactating rhesus macaques. Antimicrob Agents Chemother. 2005;49:2093-2094.

23. Palombi L, Pirillo MF, Marchei $E$, Jere $H$, Sagno JB, Luhanga $\mathrm{R}$, Floridia M, Andreotti M, Galluzzo CM, Pichini S, Mwenda R, Mancinelli S, Marazzi MC, Vella S, Liotta G, Giuliano $M$. Concentrations of tenofovir, lamivudine and efavirenz in mothers and children enrolled under the Option B-Plus approach in Malawi. J Antimicrob Chemother. 2016;71:10271030.

24. Siberry GK, Jacobson DL, Kalkwarf HJ, Wu JW, DiMeglio LA, Yogev R, Knapp KM, Wheeler JJ, Butler L, Hazra R, Miller TL, Seage GR 3rd, Van Dyke RB, Barr E, Davtyan M,
Mofenson LM, Rich KC, Pediatric HIV/AIDS Cohort Study. Lower newborn bone mineral content associated with maternal use of tenofovir disoproxil fumarate during pregnancy. Clin Infect Dis. 2015;61:996-1003.

25. Pons JC, Lebon P, Frydman R, Delfraissy JF. Pharmacokinetics of interferon-alpha in pregnant women and fetoplacental passage. Fetal DiagnTher. 1995; 10:7-10.

26. Kumar AR, Hale TW, Mock RE. Transfer of interferon alfa into human breast milk. J Hum Lact. 2000;16:226-228.

27. toxnet [Internet]. Available from: http://toxnet.nlm.nih.gov/cgibin/sis/search2/r?dbs+lactmed:@term+@DOCNO+148

28. Adefovir (Hepsera) Use During Pregnancy [Internet]. [cited 2016 Mar 20]. Available from: http://www.drugs.com/pregnancy/ adefovir.html

29. Entecavir (Baraclude) Use During Pregnancy [Internet]. [cited 2016 Mar 20]. Available from: http://www.drugs.com/pregnancy/ entecavir.html

30. Han GR, Cao MK, Zhao W, Jiang HX, Wang CM, Bai SF, Yue $X$, Wang GJ, Tang $X$, Fang ZX. A prospective and open-label study for the efficacy and safety of telbivudine in pregnancy for the prevention of perinatal transmission of hepatitis $B$ virus infection. J Hepatol. 2011;55:1215-1221.

31. Telbivudine (Tyzeka) Use During Pregnancy [Internet]. [cited 2016 Mar 20]. Available from: http://www.drugs.com/pregnancy/ telbivudine.html

32. Gerada J, Borg E, Formosa D, Magro R, Pocock J. Tenofovir as rescue therapy following clinical failure to Lamivudine in severe acute hepatitis B. Mediterr J Hematol Infect Dis. 2013;5:2013035

33. Montoya-Ferrer A, Zorrilla AM, Viljoen J, Molès JP, Newell ML, Van de Perre P, Tuaillon E. High level of HBV DNA virus in the breast milk seems not to contraindicate breastfeeding. Mediterr J Hematol Infect Dis. 2015;7:2015042.

34. Ehrhardt S, Xie C, Guo N, Nelson K, Thio CL. Breastfeeding while taking lamivudine or tenofovir disoproxil fumarate: a review of the evidence. Clin Infect Dis. 2015;60:275-278. 